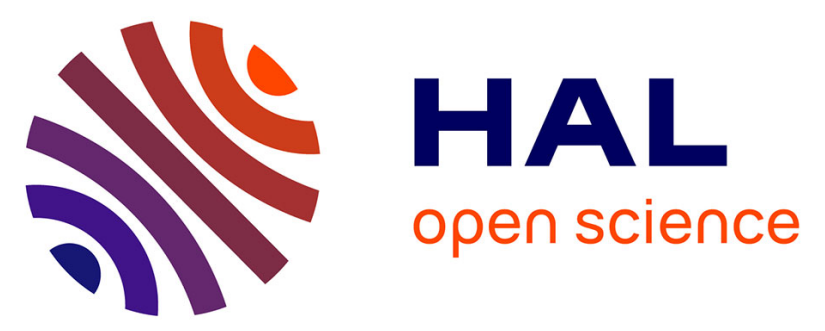

\title{
Does sulphide detoxication occur in the gills of the hydrothermal vent shrimp, Rimicaris exoculata?
}

Philippe Compère, Anne-Sophie Martinez, Mireille Charmantier-Daures, Jean-Yves Toullec, Gerhard Goffinet, Françoise Gaill

\section{To cite this version:}

Philippe Compère, Anne-Sophie Martinez, Mireille Charmantier-Daures, Jean-Yves Toullec, Gerhard Goffinet, et al.. Does sulphide detoxication occur in the gills of the hydrothermal vent shrimp, Rimicaris exoculata?. Comptes Rendus Biologies, 2002, 325 (5), pp.591-596. 10.1016/S16310691(02)01466-X . hal-02550657

\section{HAL Id: hal-02550657 https://hal.science/hal-02550657}

Submitted on 22 Apr 2020

HAL is a multi-disciplinary open access archive for the deposit and dissemination of scientific research documents, whether they are published or not. The documents may come from teaching and research institutions in France or abroad, or from public or private research centers.
L'archive ouverte pluridisciplinaire HAL, est destinée au dépôt et à la diffusion de documents scientifiques de niveau recherche, publiés ou non, émanant des établissements d'enseignement et de recherche français ou étrangers, des laboratoires publics ou privés. 


\title{
Does sulphide detoxication occur in the gills of the hydrothermal vent shrimp, Rimicaris exoculata?
}

\author{
Philippe Compère ${ }^{\mathrm{a} *}$, Anne-Sophie Martinez $^{\mathrm{b}}$, Mireille Charmantier-Daures ${ }^{\mathrm{b}}$, Jean-Yves Toullec ${ }^{\mathrm{c}}$, \\ Gerhard Goffinet $^{\mathrm{a}}$, Françoise Gaill ${ }^{\mathrm{d}}$ \\ a Laboratoire de biologie générale et de morphologie ultrastructurale, institut de zoologie, université de Liège, \\ 22, quai Édouard-Van-Beneden, B-4020 Liège, Belgique \\ b Laboratoire d'écophysiologie des Invertébrés, Université Montpellier-2, place Eugène-Bataillon, \\ 34095 Montpellier cedex 05, France \\ " Groupe "Signaux et régulations endocrines », CNRS EP 2028, École normale supérieure, 45, rue d'Ulm, \\ 75230 Paris cedex 05, France \\ ${ }^{\mathrm{d}}$ Laboratoire de Biologie cellulaire et moléculaire du développement, UMR 7622, groupe "Biologie marine ", \\ université Pierre-et-Marie-Curie, 7, quai Saint Bernard, 75252 Paris cedex 05, France
}

Received 16 May 2001; accepted 22 April 2002

Presented by Lucien Laubier

\begin{abstract}
Ultrastructural observations of the gills of the hydrothermal vent shrimp Rimicaris exoculata reveal that the epithelial cells contain numerous mitochondria clustered around unusual organelles (diameter of 0.7 to $2.5 \mu \mathrm{m}$ ) containing membrane stacks. These organelles were termed sulphide-oxidising bodies (SOBs) by structural analogy with organelles observed in the tissues of species adapted to sulphide-rich environments. Moreover, in the gills of $R$. exoculata, mitochondria display numerous electron-dense granules in their stroma. Such ultrastructural features suggest that sulphide detoxication may probably occur in the gills of $R$. exoculata. Comparable structures were also described in the gills of other hydrothermal vent species, as the alvinellid Pompeii worms that, as R. exoculata, are housing ectosymbiotic bacteria. To cite this article: Ph. Compère et al., C. R. Biologies 325 (2002) 1-6. (C) 2002 Académie des sciences / Éditions scientifiques et médicales Elsevier SAS
\end{abstract}

\section{sulphide adaptation / symbiosis / deep-sea / Crustaceans}

Résumé - Y a-t-il détoxication des sulfures dans les branchies de la crevette hydrothermale, Rimicaris exoculata? L'observation ultrastructurale des branchies des crevettes hydrothermales Rimicaris exoculata montre que les cellules épithéliales contiennent de nombreuses mitochondries groupées autour d'organites particuliers, de 0,7 à $2,5 \mu \mathrm{m}$ de diamètre, dont le contenu présente un ou plusieurs empilements de membranes. Ces organites ont été appelés corps oxydant les sulfures (COS), en anglais sulphide-oxidising bodies (SOBs), par analogie structurale avec des organites identifiés dans les tissus d'espèces adaptées à des milieux riches en sulfures. De plus, dans les branchies de $R$. exoculata, des granules denses aux électrons sont présents dans le stroma des mitochondries. Ces caractéristiques ultrastructurales suggèrent que les cellules de l'épithélium branchial de $R$. exoculata sont impliquées dans la détoxication des sulfures. Des structures comparables ont été décrites dans les branchies d'autres espèces hydrothermales, telles que des vers alvinellidés qui, comme $R$. exoculata, hébergent des bactéries ectosymbiotiques. Pour citer cet article : Ph. Compère et al., C. R. Biologies 325 (2002) 1-6. () 2002 Académie des sciences / Éditions scientifiques et médicales Elsevier SAS

\section{adaptation aux sulfures / symbioses / abyssal / Crustacés}

\footnotetext{
*Correspondence and reprints.

E-mail address: pcompere@ulg.ac.be (P. Compère).
} 


\section{- Version abrégée}

Par leur organisation, les branchies de Rimicaris exoculata (Alvinocarididae) ressemblent à celles des crevettes Palaemonidés : ce sont des phyllobranchies limitées par un épithélium de cellules à «collerette» (flange cells). Les « collerettes » de ces cellules bordent la face interne de la cuticule et sont dépourvues d'organites, tandis que les péricaryons, qui contiennent tous les organites cellulaires, font saillie dans l'hémocoele, où ils se rejoignent pour former ensemble un septum médian. Les cellules épithéliales à « collerette » de R. exoculata et celles des crevettes Palaemonidés présentent toutefois un certain nombre de caractéristiques ultrastructurales qui leurs sont propres.

Exclusivement distribuées au niveau des péricaryons, comme chez les Palaemonidés, les mitochondries de $R$. exoculata apparaissent plus nombreuses. Elles présentent également un plus grand nombre de crêtes régulièrement ordonnées et contiennent souvent des granules denses aux électrons $(100 \mathrm{~nm}$ de diamètre) dans leur stroma. Mais la différence majeure entre l'épithélium branchial des crevettes littorales (Palaemonidés) et celui de $R$. exoculata réside dans la présence chez cette espèce, au niveau des péricaryons, d'organites particuliers, souvent entourés de mitochondries avec lesquelles ils semblent associés. La taille de ces organites varie de 0,7 à $2,5 \mu \mathrm{m}$ de diamètre. D'aspect hétérogène et limités par une simple membrane, ces organites ressemblent à des lysosomes, mais s'en distinguent par la présence d'un ou de plusieurs empilements réguliers de membranes qui occupent la plus grande partie de leur volume.

Les caractéristiques structurales des mitochondries de l'épithélium branchial de $R$. exoculata correspondent à celles que l'on rencontre dans les branchies d'annélides polychètes (Alvinella pompejana et Paralvinella grasslei) vivant dans les parois de cheminées hydrothermales, un environnement où la concentration en sulfures dissous peut atteindre $300 \mu \mathrm{mol} \mathrm{l}^{-1}$ ou encore chez une espèce de turbellarié du méiobenthos, Solenofilomorpha funiculis, connue pour sa capacité à détoxiquer les sulfures. Par ailleurs, la présence d'organites cellulaires à empilements membranaires, associés aux mitochondries, a été observée à plusieurs reprises dans les tissus d'espèces adaptées à des environnements riches en sulfures. Elle est considérée comme un indice morphologique de l'existence d'un mécanisme de détoxication des sulfures. C'est ainsi que des organites identiques à ceux observés chez
R. exoculata sont bien connus chez le bivalve Solemya reidi, dont l'épithélium branchial héberge des bactéries symbiotiques. Il a été montré chez cette espèce que l'oxydation des sulfures en thiosulfates ne s'effectuait pas dans les bactéries symbiotiques, mais bien dans les tissus de l'hôte, précisément dans les mitochondries et dans ces organites particuliers qui ont été dénommés sulphide-oxidising bodies (SOBs), en français «corps oxydant les sulfures »(COS), termes que nous proposons d'adopter pour désigner les organites de même structure rencontrés dans l'épithélium branchial de $R$. exoculata. Récemment, des structures semblables ont été décrites dans les branchies de vers polychètes alvinellidés (A. pompejana et $P$. grasslei) ainsi que dans l'intestin et le tégument de l'échiurien, Urechis caupo. Chez $U$. caupo, les produits terminaux de l'oxydation des sulfures s'accumuleraient dans les SOBs, qui sont considérés comme des lysosomes particuliers assurant la lyse des mitochondries (endommagées ?) après oxydation des sulfures.

Les résultats obtenus chez $R$. exoculata sont les premiers à fournir des indices structuraux suggérant un rôle des branchies dans la détoxication des sulfures chez un crustacé, alors que l'épithélium branchial des crustacés décapodes est essentiellement connu pour sa participation dans la respiration et l'osmorégulation. C'est également la première fois que sont décrites chez un crustacé des structures intracellulaires probablement impliquées dans la détoxication des sulfures. Chez $R$. exoculata, comme chez $S$. reidi et A. pompejana, la présence de COS associés à des mitochondries modifiées suggère que l'oxydation des sulfures est couplée à une production d'ATP. L'existence d'un tel mécanisme a été démontrée chez $S$. reidi, l'oxydation des sulfures représentant dès lors un apport énergétique direct pour l'organisme.

D'un point de vue écophysiologique, $R$. exoculata rejoint les espèces hydrothermales, en particulier les Alvinellidés («vers de Pompéi »), qui vivent sur des cheminées actives. Comme les vers alvinellidés, les crevettes $R$. exoculata sont supposées dépendre trophiquement des bactéries chimioautotrophes qu'elles hébergent et paraissent détoxiquer les sulfures au niveau de leurs branchies. Les résultats obtenus chez $R$. exoculata n'excluent toutefois pas l'intervention des branchies dans d'autres fonctions physiologiques, ni l'existence d'autres mécanismes de détoxication des sulfures, plusieurs processus pouvant coexister dans un même organisme. 


\section{Introduction}

Caridean shrimps from the family Alvinocarididae, and especially from the species Rimicaris exoculata Williams and Rona, 1986 [1], dominate the megafauna of most of the Mid-Atlantic Ridge hydrothermal vent fields at depths reaching $3500 \mathrm{~m}$ [2]. These shrimps form particularly dense swarms (up to 2500 individuals $\mathrm{m}^{-2}$ ), hiding the rock, around sulphide black smoker chimneys on tops of hydrothermal mounds [2-5]. The water environment around the aggregations is turbulent, toxic and fluctuating because of mixing of the oxic, cold sea water $\left(1-2{ }^{\circ} \mathrm{C}\right)$ with the hot $\left( \pm 350{ }^{\circ} \mathrm{C}\right)$ and acid (pH 3.0 to 4.0) hydrothermal fluid that is rich in dissolved and particulate metals and inorganic sulphide compounds $[6,7]$. The shrimps are regarded as primary consumers having a bacterial diet. They are supposed to graze on the free-living, surface bacterial community and/or to feed off the numerous epibiotic bacteria, regarded by many authors as ectosymbionts, which grow on their mouth parts as well as on the inner surface of their gill chamber $[4,5,8-10]$. As the free-living bacterial mats, this epibiotic bacterial community is dominated by a genetic single type of filamentous e-proteobacteria [11] and shows a high sulphur-dependent chemoautotrophic activity [9, 12]. In this view, shrimps appear to be particularly exposed to toxic hydrothermal fluid sulphides that are potential poisons for their aerobic respiration but also essential nutriments for their ectosymbionts. It is thus hypothesised that transport, elimination and/or detoxication processes may occur in the gill chamber of the shrimps, usually solely devoted to ionic or osmotic regulation, exchanges with epibionts and/or protection against toxic substances.

To investigate their possible participation in such exchange and/or detoxication processes and to look for intracellular features potentially related to these processes, the gills of $R$. exoculata were examined at the ultrastructural level and compared with those of a littoral palaemonid shrimp, Palaemon adspersus.

\section{Material and methods}

Vent shrimps Rimicaris exoculata were captured in August 1997 at the Rainbow site of the Mid-Atlantic Ridge (N.O. Atalante MARVEL cruise). The gills were dissected, fixed aboard in $2.5 \%$ glutaraldehyde in $0.25 \mathrm{M}$ Na-cacodylate buffer ( $\mathrm{pH} 7.4$ ) adjusted at 950 mosm $\mathrm{kg}^{-1}$ with sucrose. They were kept for several weeks at $4{ }^{\circ} \mathrm{C}$ in washing buffer. In the laboratory, they were fixed again for $2 \mathrm{~h}$ in a buffered $2.5 \%$ glutaraldehyde solution and post-fixed for $1 \mathrm{~h}$ in $1 \%$
$\mathrm{OsO}_{4}$ before embedding in epoxy resin according to a routine procedure (ethanol/epoxypropane dehydration). Palaemon adspersus shrimps were collected in the Mediterranean littoral lagoons close to Montpellier (France). Gills were glutaraldehyde-fixed for $2 \mathrm{~h}$ and processed as those of $R$. exoculata. Ultra-thin sections were performed with a diamond knife on a Reichert-Jung ultra-microtome (Ultracut E), contrasted with uranyl acetate (alcoholic solution) and lead citrate, and observed in a Jeol JEM 100-SX electron microscope at $80 \mathrm{kV}$ of accelerating voltage.

\section{Results and discussion}

As previously reported [1, 8], R. exoculata possesses phyllobranchiate gills. In their organisation, they resemble those of $P$. adspersus and other palaemonid shrimps [13-16]. The gill epithelium mainly consists of flange cells. The large perikaryons of these cells protrude into the haemocoel and make contact with median septum, while the flanges form a thin cytoplasmic sheet at the inner surface of the cuticle (Fig. 1). The gill epithelial cells of $R$. exoculata however contrast with those of $P$. adspersus by some ultrastructural features. The number of mitochondria is much higher in the gill epithelial cells of $R$. exoculata (Figs. 1 and 2) than in those of P. adspersus and other non-vent decapod crustaceans [16-19]. In addition, the mitochondria are distributed exclusively in the perikaryons of the flange cells (Figs. 1 and 2), while they are absent from the flanges where cell organelles are almost completely missing, except for some rough endoplasmic reticulum cisternae (not shown). They also show numerous orderly-arranged cristae and regularly contain a number of small electron-dense granules (diameter of approximately $100 \mathrm{~nm}$ ) in their stroma (Fig. 3). The cell bodies contain peculiar organelles that regularly appear to be associated with clustered mitochondria (Figs. 1, 2 and $4)$. These organelles resemble lysosomes by their heterogeneous electron-dense aspect and are single membrane-bounded. Their average diameter ranges from 0.7 to $2.5 \mu \mathrm{m}$. Beside a heterogeneous electrondense matrix, their content is characterised by the presence of several stacks of parallel membranes (Figs. 4 and 5).

Arrays of mitochondria and unusual organelles similar to those observed in the gills of $R$. exoculata were observed in different tissues of thiobiotic and/or sulphide adapted species in which they have been reported to act in sulphide detoxication. Mitochondria displaying numerous ordered cristae and containing small dense granules, have been reported in the gills of the 'Pompeii worms' Alvinella pompejana and Paralvinella 

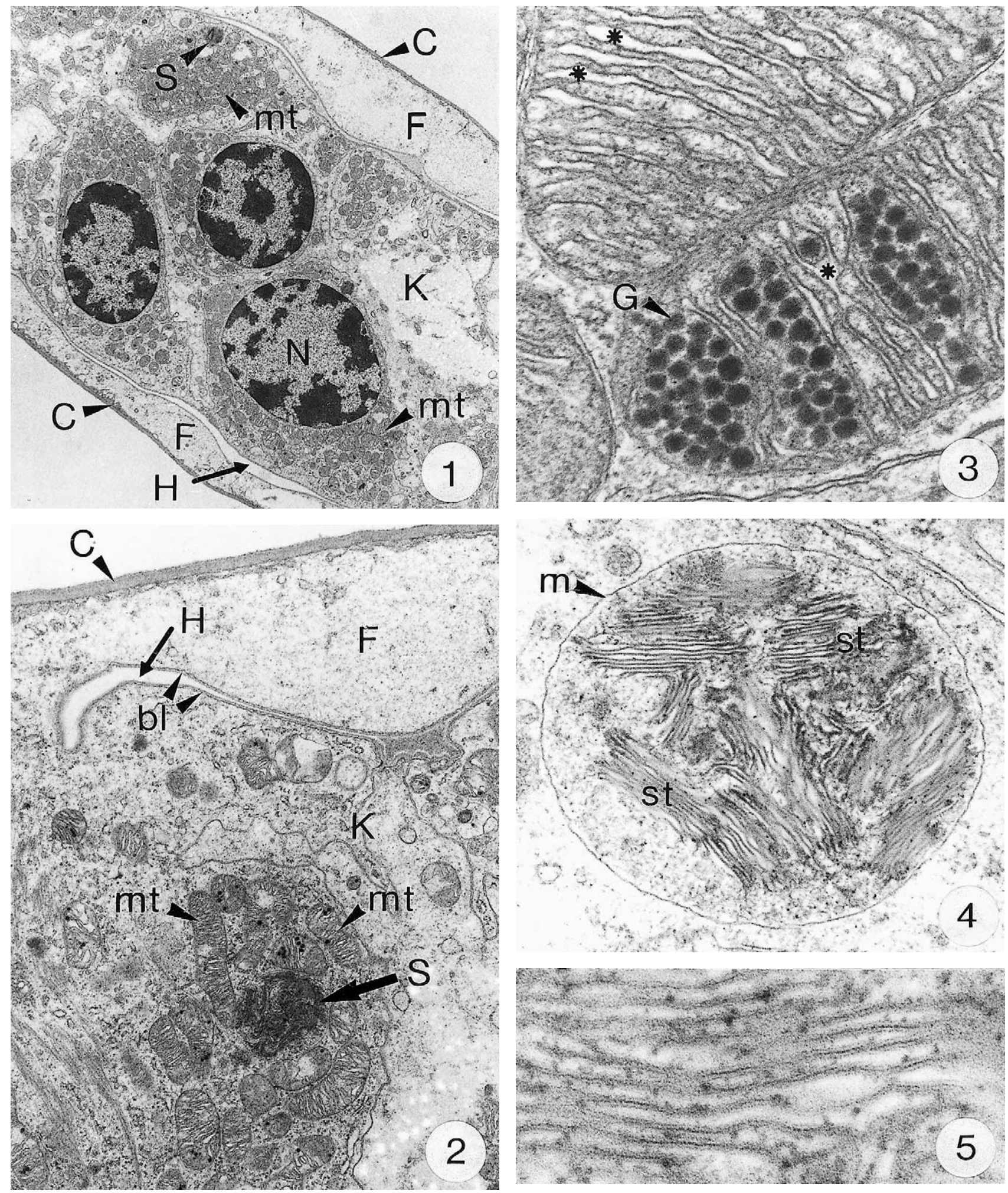

Figs. 1-5. Ultra-thin sections of gill lamellae of $R$. exoculata. 1. General view of a lamella with flange cells forming the gill epithelium $(\times 2250)$. 2. Flange cell showing a cluster of mitochondria $(\mathbf{m t})$ around a sulphide-oxidising body $($ SOB $)(\times 8000)$. 3. Detail of mitochondria (mt) with orderly arranged cristae (asterisk) and containing electron dense granules $(\mathbf{g})(\times 45000)$. 4. Detail of a SOB showing its single bounding membrane $(\mathbf{m})(\times 30000)$. 5. High magnification of a membrane stack in a SOB $(\times 160000)$. bl, basal lamina; $\mathbf{C}$, cuticle; $\mathbf{F}$, flange (cytoplasmic extension); $\mathbf{G}$, electron-dense granules; $\mathbf{H}$, hemolymph; $\mathbf{K}$, perikaryons of flange cells of the gill epithelium; N, nucleus; $\mathbf{m}$, membrane; mt, mitochondria; $\mathbf{S}$, sulphide-oxidising bodies; st, membrane stack; asterisks $\star$, mitochondrial cristae. 
grasslei [20] that dwell on active sulphide chimney walls with environmental $\mathrm{H}_{2} \mathrm{~S}$ concentrations up to $300 \mu \mathrm{mol} \mathrm{l}^{-1}$ [21]. Similar characteristic features of mitochondria also occur in the meiobenthic, thiobiotic turbellarian, Solenofilomorpha funilis, a species able to detoxify sulphides, despite the absence of associated or symbiotic bacteria [22].

Electron-dense organelles displaying membrane stacks were originally described and termed 'sulphideoxidising bodies' (SOBs) in the gill of the symbiontcontaining clam Solemya reidi [23], which was recognised to detoxify sulphide in its tissues and not in its symbiotic bacteria. In this species, enzymatic oxidation of sulphide to thiosulphate was demonstrated to occur in mitochondria and SOBs, and to be coupled with ATP production, thus providing additional energy to the organism [24, 25]. Similar SOBs were reported from the hindgut and tegumental tissues of the sulphidetolerant echiurid worm, Urechis caupo [26, 27], in which sulphide oxidation to thiosulfate was demonstrated to be performed by crude homogenate of the tissues [28]. The latter authors suggested that U. caupo SOBs could be lysosomal structures that digest damaged mitochondria and accumulate sulphur compounds, perhaps the end products of sulphide oxidation. Some of the R. exoculata SOBs also exhibit lysosomal features (e.g. an heterogeneous content), but the presence of ordered membrane stacks does rather suggest a functional role and remains enigmatic. Cytoplasmic structures resembling SOBs were also described in the gills of Pompeii worms [20], but the authors have not considered their role.

Thus, the present data suggest that sulphide detoxication may occur in the gill epithelium of the hydrothermal shrimp R. exoculata, since SOBs and mitochondria were regularly observed in the tissues of species adapted to sulphide-rich environments [23, 24, 26-28]. The simultaneous presence and the association of both types of organelles are regarded as a morphological evidence of the occurrence of a sulphide detoxication process. Moreover, the sulphide detoxication mechanism in $R$. exoculata should be different from that described in the Pacific vent crab Bythograea thermydron that is reported to tolerate at least $1.4 \mathrm{mM}$ sulphide with little effect [29]. In the latter species, such a tolerance is apparently achieved in the digestive gland by oxidising sulphide to relatively non-toxic thiosulphate that is accumulated in the haemolymph and probably eliminated across the gills [29, 30]. The sulphide oxidation activity in the gills of $B$. thermydron was considered as not significant by these authors. Such a difference in the sulphide oxidation tissue site between $B$. thermydron and $R$. exoculata may be explained by behavioural and diet differences between these species. $B$. thermydron is a top-consumer that can adapt the duration of its stays in a sulphide-rich environment. It can also regulate the water flow through its gills just to compensate its own oxygen demand [30]. In contrast, the shrimp $R$. exoculata, considered as a primary consumer, stays almost permanently close to the hydrothermal fluid, either to graze on chimneys or most presumably to supply sulphide to the ectosymbiotic bacteria growing on its mouthparts and gill chamber walls $[4,5$, 10]. Despite the presence of bacteria that could detoxify the fluid by using sulphide in their chemosynthetic activities, the gills of the shrimp are particularly exposed and continuously bathed by the sulphide-rich water flow passing through the gill chamber. Moreover, it is obvious that the very thin gill cuticle of $R$. exoculata (less than $0.5 \mu \mathrm{m}$ thick) cannot act as a barrier against sulphide, which is known to permeate easily through tissues and tegumental structures [31]. Thus, sulphide may easily reach the haemolymph by passing through the cuticle and the flange of the gill epithelial cells. Most of the sulphide detoxication could occur during the transit of the haemolymph in the gill haemocoel in close contact with the epithelial cell bodies, rich in mitochondria and SOBs.

\section{Conclusion}

The present ultrastructural observations are the first to suggest that the gills of a decapod crustacean can act as sulphide detoxication organs. In addition, the presence of SOBs and mitochondria exhibiting characteristic features in the gill epithelium of $R$. exoculata strongly suggests that sulphide detoxication could occur at the level of both organelles and might be coupled with ATP production providing energy to the shrimps as it is the case in $S$. reidi $[24,25]$.

These findings exclude neither other physiological functions of the gills of $R$. exoculata nor the involvement of other tolerance mechanisms to high environmental concentrations of sulphide, since multiple tolerance mechanisms have been simultaneously developed in other species $[28,31,32]$.

On the other hand, the fact that $R$. exoculata has developed tolerance to sulphide can also be regarded as one more convergent ecophysiological adaptation of these shrimps (which farm bacterial ectosymbionts) with the other vent species housing endosymbiotic or ectosymbiotic bacteria. As previously pointed out by Desbruyères et al. [21], such an analogy appears particularly close when considering the Pompeii worms that also dwell on active sulphide chimneys. These 
worms are supposed to be trophically dependent on the bacterial communities they house, and are also supposed to detoxify sulphide in their gills $[20,21]$.
However, in shrimps and Pompeii worms, characterisation and biochemical evidence for a sulphide oxidation activity and process remain to be provided.

Acknowledgements. This work was partly funded by the EC MAST programme MARVEL, the VENTOX programme EVK3-1999-00056P and the French programme DORSALES. The authors are very grateful to Dr Daniel Soyer (director scientist of the research project in the DORSALES programme) and to Dr Daniel Desbruyères (chief scientist of the MARVEL cruise). The authors wish also to express their appreciation to Mrs N. Decloux (ultramicrotomy) and Mrs C. Breeur (iconography) for their excellent technical assistance.

\section{References}

[1] A.B. Williams, P. Rona, Two new caridean shrimps (Bresiliidae) from a hydrothermal field on the Mid-Atlantic Ridge, J. Crust. Biol. 6 (1986) 446-462.

[2] C.L. Van Dover, B. Fry, J.F. Grassle, S. Humphris, P.A. Rona, Feeding biology of the shrimp Rimicaris exoculata at hydrothermal vents on the mid-Atlantic Ridge, Mar. Biol. 98 (1988) 209-216.

[3] M. Segonzac, Les peuplements associés à l'hydrothermalisme océanique du Snake Pit (dorsale médio-atlantique ; $23^{\circ} \mathrm{N}, 3480 \mathrm{~m}$ ): composition et distribution de la mégafaune, C.R. Acad. Sci. Paris, Ser. III 314 (1992) 593-600.

[4] A.V. Gebruk, N.V. Pimenov, A.S. Sauvichev, Feeding specialization of bresiliid shrimps in the TAG site hydrothermal community, Mar. Ecol. Progr. Series 98 (1993) 247-253.

[5] M. Segonzac, M. de Saint Laurent, B. Casanova, L'énigme du comportement trophique des crevettes Alvinocarididae des sites hydrothermaux de la dorsale médio-Atlantique, Cah. Biol. mar. 34 (1993) 535-571.

[6] J.M. Edmond, A.C. Campbell, M.R. Palmer, G.P. Klinkhammer, C.R. German, H.N. Edmonds, H. Elderfield, G. Thomson, P. Rona, Time series studies of vent fluids from the TAG and MARK sites $(1986,1990)$ Mid-Atlantic Ridge: a new solution chemistry model and mechanism for $\mathrm{Cu} / \mathrm{Zn}$ zonation in massive sulphide orebodies, in: L.M. Parson, C.L. Walker, D.R. Dixon (Eds.), Hydrothermal Vents and Processes, Geol. Soc. Spec. Publ. $\mathrm{n}^{\circ} 87,1995$, pp. 77-86.

[7] R.A. Mills, Hydrothermal deposits and metaliferous sediments from TAG, $26^{\circ}$ N Mid-Atlantic Ridge, in: L.M. Parson, C.L. Walker, D.R. Dixon (Eds.), Hydrothermal Vents and Processes, Geol. Soc. Spec. Publ. n ${ }^{\circ} 87$, 1995, pp. 121-132.

[8] B. Casanova, M. Brunet, M. Segonzac, L'impact d'une épibiose bactérienne sur la morphologie fonctionnelle de crevettes associées à l'hydrothermalisme médio-Atlantique, Cah. Biol. mar. 34 (1993) 573-588.

[9] C.L. Van Dover, Ecology of the Mid-Atlantic Ridge hydrothermal vents, Hydrothermal Vents and Processes, in: L.M. Parson, C.L. Walker, D.R. Dixon (Eds.), Hydrothermal Vents and Processes, Geol. Soc. Spec. Publ. $\mathrm{n}^{\circ}$ 87, 1995, pp. 257-294.

[10] M.F. Polz, J.J. Robinson, C.M. Cavanaugh, Trophic ecology of massive shrimp aggregations at a Mid-Atlantic Ridge hydrothermal vent site, Limnol. Oceanogr. 43 (1998) 1631-1638.

[11] M.F. Polz, C.M. Cavanaugh, Dominance of one bacterial phylotype at a Mid-Atlantic Ridge hydrothermal vent site, Proc. Natl Acad. Sci. USA 92 (1995) 7232-7236.

[12] C.O. Wirsen, H.W. Jannasch, S.J. Molyneaux, Chemosynthetic microbial activity at Mid-Atlantic Ridge hydrothermal vent sites, J. Geophys. Res. 98 (B6) (1993) 9693-9703.

[13] E.J. Allen, On the minute structure of the gills of Palaemonetes varians, Q. J. Microsc. Sci. 34 (1893) 75-84.

[14] L. Cuénot, Études physiologiques sur les Crustacés Décapodes, Arch. Biol. 13 (1893) 245-303 (planches XI-XIII).

[15] D.G. Doughtie, K.R. Rao, Ultrastructural changes induced by sodium pentachlorophenate in the grass shrimp, Palaemonetes pugio, in relation to the molt cycle, in: K.R. Rao (Ed.), Pentachlorophenol: Chemistry, Pharmacology and Environmental Toxicology, Plenum Press, New York, 1978, pp. 213-250.
[16] H.H. Taylor, E.W. Taylor, Gills and lungs: the exchanges of gas and ions, Microscopic Anatomy of Invertebrates, vol. 10, Decapod Crustacea, Wiley-Liss, Inc., 1992, pp. 203-293.

[17] C.A. Foster, H.D. Howse, A morphological study on gill of the brown shrimp, Penaeus aztecus, Tissue Cell 10 (1978) 77-92.

[18] J.A. Barra, A. Péqueux, W. Humbert, A morphological study on gills of a crab acclimated to fresh water, Tissue Cell 15 (1983) 583-596.

[19] P. Compère, S. Wanson, A. Péqueux, R. Gilles, G. Goffinet, Ultrastructural changes in the gill epithelium of the green crab Carcinus maenas in relation to external salinity, Tissue Cell 21 (1989) 299-318.

[20] C. Jouin, F. Gaill, Gills of hydrothermal vent annelids: structure, ultrastructure and functional implications in two alvinellid species, Prog. Oceanogr. 24 (1990) 59-69.

[21] D. Desbruyères, P. Chevaldonné, A.M. Alayse, D. Jollivet, F.H. Lallier, C. Jouin-Toulmont, F. Zal, P.M. Sarradin, R. Cosson, J.C. Caprais, C. Arndt, J. O'Brien, J. Guezennec, S. Hourdez, R. Riso, L. Laubier, A. Toulmond, Biology and ecology of the 'Pompeii worm' (Alvinella pompejana Desbruyères and Laubier), a normal dweller of an extreme deep-sea environment: a synthesis of current knowledge and recent developments, Deep-sea Res, II 45 (1998) 383-422.

[22] J.E. Duffi, S. Tyler, Quantitative differences in mitochondrial ultrastructure of a thiobiotic and oxybiotic turbellarian, Mar Biol. 83 (1984) 95-102.

[23] M.A. Powell, G.N. Somero, Sulfide oxidation occurs in the animal tissue of the gutless clam Solemya reidi, Biol. Bull. 169 (1985) 164-181.

[24] M.A. Powell, G.N. Somero, Hydrogen sulfide oxidation is coupled to oxidative phosphorylation in mitochondria of Solemya reidi, Science 233 (1986) 563-566.

[25] J. O'Brien, R.D. Vetter, Production of thiosulphate during sulphide oxidation by mitochondria of the symbiont containing bivalve Solemya reidi, J. Exp. Biol. 149 (1990) 133-148.

[26] J.G. Menon, A.J. Arp, Adaptations of the respiratory hindgut of a marine echiuran worm, J. Morphol. 214 (1992) 131-138.

[27] J.G. Menon, A.J. Arp, The integument of the marine echiuran worm Urechis caupo, Biol. Bull. 185 (1993) 440-454.

[28] A.J. Arp, J.G. Menon, D. Julian, Multiple mechanisms provide tolerance to environmental sulfide in Urechis caupo, Am. Zool. 35 (1995) $132-144$.

[29] R.D. Vetter, M.E. Wells, A.L. Kurtsman, G.N. Somero, Sulpfide detoxification by the hydrothermal vent crab Bythograea thermydron and other decapod crustaceans, Physiol. Zool. 60 (1987) 121-137.

[30] L.A. Gorodezky, J.J. Childress, Effects of sulfide exposure history and hemolymph thiosulfate on oxygen-consumption rates and regulation in the hydrothermal vent crab Bythograea thermydron, Mar. Biol. 120 (1994) $123-131$.

[31] G.N. Somero, A.E. Anderson, J.J. Childress, Transport metabolism and detoxification of hydrogen sulphide in animals from sulphide-rich marine environments, Rev. Aquat. Sci. 1 (1989) 591-614.

[32] M. Segonzac, T. Comtet, P. Chevaldonné, Epibiosis in two invertebretate species associated to oceanic hydrothermalism: an example of adaptative convergence, Cah. Biol. Mar. 38 (1997) 139-140. 